7. Reprod. Fert. (1972) 30, 71-81

\title{
VIABILITY AND SURVIVAL OF MOUSE EMBRYOS FOLLOWING PARENTAL EXPOSURE TO HIGH TEMPERATURE
}

\author{
A. R. BELLVE** \\ Ruakura Research Centre, Private Bag, Hamilton, New Zealand
}

(Received 2nd June 1971, accepted 22nd Fuly 1971)

\begin{abstract}
Summary. Albino ICR mice, 384 females and 48 males, were allocated to control or stress treatments. For the latter, animals were exposed to $34.5^{\circ} \mathrm{C}$ and $65 \%$ relative humidity for a period of $24 \mathrm{hr}$. The treatment of males commenced $48 \mathrm{hr}$ before a 6-day mating schedule and of females, at 16.00 hours on the day a copulatory plug was detected. The females were killed $54 \mathrm{hr}$ or 10 days after a plug had been detected. The developmental stages of embryos recovered at $54 \mathrm{hr}$ were recorded and four-cell and eight-cell ova were incubated in $\left[{ }^{3} \mathrm{H}\right]$ uridine and subjected to autoradiography. Females killed at Day 10 of gestation gave estimates of pre- and postimplantation embryonic mortality.

A significant increase in rectal temperatures (approximately $2^{\circ} \mathrm{C}$ ) following treatment was taken as indicating stress had occurred. Extensive developmental retardation and/or arrest among embryos recovered from stressed females at $54 \mathrm{hr}$ resulted in an increase in the proportion of two-, three- and four-cell embryos. This retardation was coincident with fewer blastomeres of four-cell $(P<0.01)$ and eight-cell embryos $(P<0.05)$ being able to incorporate $\left[{ }^{3} \mathrm{H}\right]$ uridine in comparison to those from control females. After male stress, developmental retardation was evident as an accumulation $(P<0.05)$ of four-cell embryos but only the eight-cell embryos exhibited a reduction $(P<0.05)$ in the number able to incorporate $\left[{ }^{3} \mathrm{H}\right]$ uridine.
\end{abstract}

\section{INTRODUCTION}

The phenomenon of embryonic mortality due to heat stress appears to parallel that observed during culture in vitro of mouse embryos in the presence of actinomycin D (Skalko \& Morse, 1969), an inhibitor of DNA-dependent RNA synthesis. Inhibition of ribosomal RNA synthesis is implied in several reports concerning anucleolate amphibian eggs (Brown, 1964; Hallberg \& Brown, 1969). A similar failure of RNA synthesis may also occur in the nucleoli of four- and eight-cell mouse embryos recovered from heat-stressed females (Elliott, 1968). Investigations were, therefore, initiated in an attempt to define the mechanisms involved in embryonic mortality and thereby help to elucidate the requirements for normal development.

\footnotetext{
* Present address: Laboratory of Human Reproduction and Reproductive Biology, Harvard Medical School, 45 Shattuck Street, Boston, Massachusetts 02115, U.S.A.
} 
The objective in the current study was to verify the inhibition of $\left[{ }^{3} \mathrm{H}\right]$ uridine incorporation in embryos from heat-stressed females and investigate the possibility of a similar malfunction in embryos fertilized by similarly stressed males. The validity of assessing embryonic viability in this manner was checked by a comparison with data on fetal survival at mid-pregnancy. Furthermore, the combined effects of male and female heat stress on embryonic mortality were determined.

\section{MATERIALS AND METHODS}

\section{Experimental design}

The 384 female and 48 male ICR albino mice (Institute of Cancer Research, Philadelphia, $\mathrm{Pa}$.) of proven fertility were housed in an environmental control

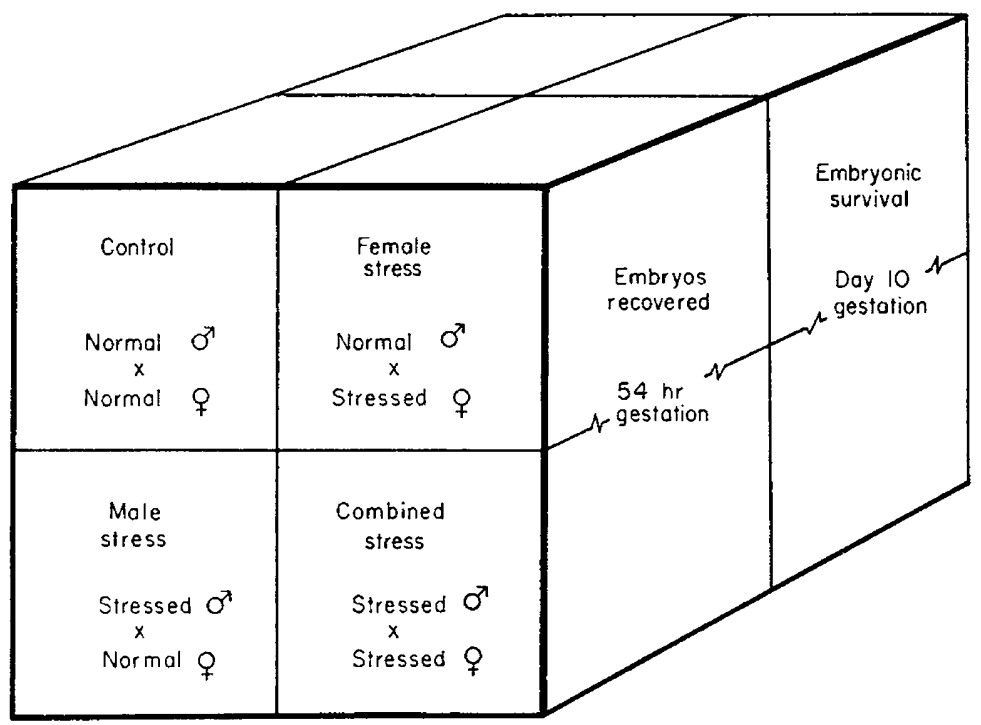

TeXT-FIG. 1. Schematic presentation of the nested factorial experiment. Each replicate had four normal and four stressed males treated at the same time. Eight females mated to each male were allocated as follows: two control and two stressed females killed at 54 $\mathrm{hr}$ gestation, and two control and two stressed females killed on Day 10. This basic design was replicated six times using 48 male and 384 female mice. A total of 2172 embryos were recovered from females killed at $54 \mathrm{hr}$ gestation, of which 1421 four-cell and eightcell were subjected to autoradiography.

chamber maintained at $21 \pm 2^{\circ} \mathrm{C}$. Males and females to be stressed were placed for a $24-\mathrm{hr}$ period in a heated cabinet maintained at $34.5 \pm 0.2^{\circ} \mathrm{C}$ and $65 \pm 5 \%$ relative humidity.

Males to be stressed within each replicate were placed in the heated cabinet at the same time (Day 1). Control and stressed males were then placed with parous 10- to 14-week-old females at 17.00 hours on Day 3. Mating was allowed to continue for 6 consecutive days (Days 3 to 8 inclusive), or until eight females each had a copulatory plug by an individual male. Five males failed to mate with eight females within the 6-day period. They were replaced with five other males, each mated to eight females. This mating system was selected to 
maximize embryonic mortality in the absence of fertilization failure (Burfening, Elliott, Eisen \& Ulberg, 1970). Mated females allocated to the stress treatment were exposed from 16.00 hours on the day a copulatory plug was detected. Rectal temperatures were recorded for all animals before treatment, and again for stressed animals immediately after being removed from the heated cabinet. Since prior excitation of mice can cause undue variation in rectal temperature, all recordings were taken with expediency and a minimum of struggling, using a tele-thermometer (Yellowspring Instrument Co.). Treated animals were then returned to the environmental control chamber.

The study involved a nested factorial experiment (Text-fig. 1) using four control and four stressed males in each replicate. The eight females mated by each male were allocated at random as follows: two control and two stressed females killed at $54 \pm 1 \mathrm{hr}$ after a plug was observed, and two control and two stressed females killed on Day 10 of gestation. Thus, eight males and sixty-four females were used in each replicate to give the treatment groups: control, female stress, male stress and combined stress (Text-fig. 1). This basic design was replicated six times within a 2-month period.

\section{Determination of viability}

Females were killed $54 \mathrm{hr}$ after a plug was detected. The oviducts were removed and their contents flushed into an embryological watchglass using the culture medium (BMOC) described by Brinster (1969). Embryos from individual females were observed microscopically and classified according to stage of development.

Those with four or more blastomeres were then incubated in $0.2 \mathrm{ml} \mathrm{BMOC}$ containing $20 \mu \mathrm{Ci} / \mathrm{ml}\left[{ }^{3} \mathrm{H}\right]$ uridine, with a specific activity of $15 \cdot 1 \mathrm{Ci} / \mathrm{mm}(\mathrm{New}$ England Nuclear Corp.), under light paraffin oil in 60-mm Petri dishes. The incubator was maintained at $37.5^{\circ} \mathrm{C}$ and supplied with $5 \% \mathrm{CO}_{2}$ in air. At the end of either $60 \mathrm{~min}$ or $30 \mathrm{~min}$, four- and eight-cell embryos, respectively, were transferred to Brinster's medium containing $45.0 \mathrm{mg} /$ litre of non-radioactive uridine for $10 \mathrm{~min}$ at $22^{\circ} \mathrm{C}$. The zona pellucida was then removed with pronase (Calbiochem) and the embryos from individual females were fixed in cold acetic acid:ethanol $(1: 3)$ for 1 to 2 min, placed on microscope slides and allowed to dry. Prepared slides were transferred to a dark room and coated with emulsion (Kodak Nuclear Track emulsion, type NTB3) and exposed for 12 to 14 days at $5^{\circ} \mathrm{C}$. The preparations were subsequently developed using standard procedures (Kodak, 1966) and stained with Azure B. On examination, fourcell (four to six blastomeres) and eight-cell (seven to ten blastomeres) embryos were classified according to the proportion of their blastomeres with labelled nucleoli as follows:

(a) non-labelled, none of the blastomeres incorporated $\left[{ }^{3} \mathrm{H}\right]$ uridine;

(b) partially labelled, some but less than $50 \%$ of the blastomeres were labelled;

(c) incompletely labelled, $50 \%$ or more, but not all, blastomeres were labelled;

(d) completely labelled, all blastomeres were labelled. 
Owing to the prolonged exposure to $\left[{ }^{3} \mathrm{H}\right]$ uridine, its presence in functional nucleoli was generally in marked contrast both to background staining and to those nucleoli of embryos which had not incorporated isotope. In those instances where incorporation was marginal, blastomeres with less than ten silver grains over the nucleoli were classified as negative.

Females killed at Day 10 of gestation provided estimates of pre- and postimplantation mortality. The numbers of CL, implant sites, and viable and nonviable fetuses were recorded. Fetuses were classified as non-viable if they were either absent from an implant site or present but degenerate with no heart beat detectable at autopsy.

\section{Statistical procedure}

The data were analysed (Bellvé, 1970) by a general least squares procedure (Harvey, 1960). When certain mean squares (e.g. replicate $\times$ treatment interaction) were clearly nonsignificant, they were pooled with the residual mean square to provide an appropriate error term. The analysis of male rectal temperature after treatment included estimates of treatment and replicate effects, and treatment $\times$ replicate interaction.

Female rectal temperatures and number of GL were analysed for the effects of female treatment, replicates and day of death. The remainder of the data was analysed on a 'within day of death' basis. Where necessary, the data were adjusted by covariance techniques and significance of treatment differences calculated on adjusted means using the least significant difference procedure (Snedecor \& Cochran, 1967).

\section{RESULTS}

\section{Rectal temperature}

The mean rectal temperatures of males and females following the 24-hr exposure to high temperature were approximately $2^{\circ} \mathrm{C}$ above those of control animals (Tables 1 and 2). The analysis of variance on male rectal temperature indicated that the treatment effect and replicate $\times$ treatment interaction were both significant $(P<0.01)$. Analysis of data on female rectal temperature showed a significant $(P<0.01)$ effect of treatment for those females killed at $54 \mathrm{hr}$ and those killed on Day 10 of gestation, but there was no difference between these two periods.

\section{Number of corpora lutea}

The mean numbers of cL for each treatment group at 54-hr and Day 10 of gestation are presented in Tables $I$ and 2, respectively. The analysis of variance between time of death indicated considerable variation between replicates $(P<0.05)$ for this characteristic. A significant male $\times$ female interaction $(P<$ $0 \cdot 05$ ) for animals killed on Day 10 was primarily due to a lower mean number of $\mathrm{GL}$ in the female stress group.

\section{Embryo morphology at $54 \mathrm{hr}$ gestation}

The percentage and mean number of embryos in each stage of development, 
as defined by number of blastomeres, within the four treatment groups are presented in Text-fig. 2 and Table 1, respectively. The analyses of variance on number of total embryos recovered and number of one-cell embryos did not disclose any significant treatment effects. Female treatment increased $(P<0.01)$

TABLE 1

MALE AND FEMALE REGTAL TEMPERATURE, NUMBER OF CORPORA LUTEA, EMBRYOS RECOVERED AND DISTRIBUTION OF GELL STAGES AT 54 HR GESTATION (MEAN NUMBER/ FEMALE \pm S.E.) * IN MIGE

\begin{tabular}{|c|c|c|c|c|c|c|c|}
\hline \multirow[b]{2}{*}{ Characteristic } & \multicolumn{5}{|c|}{ Treatment groups } & \multicolumn{2}{|c|}{ L.S.D. $\dagger$} \\
\hline & Control & $\begin{array}{c}\text { Female } \\
\text { stress }\end{array}$ & $\begin{array}{l}\text { Male } \\
\text { stress }\end{array}$ & $\begin{array}{l}\text { Combined } \\
\text { stress }\end{array}$ & $\pm S . E$ & $5 \%$ & $1 \%$ \\
\hline $\begin{array}{l}\text { Male temp. }\left({ }^{\circ} \mathrm{C}\right) \\
\text { Female temp. }\left({ }^{\circ} \mathrm{C}\right) \\
\text { Corpora lutea } \\
\text { Embryos recovered } \\
\text { One-cell } \\
\text { Two-cell } \\
\text { Three-cell } \\
\text { Four-cell } \ddagger \\
\text { Eight-cell } \$\end{array}$ & $\begin{array}{r}38 \cdot 22 \\
38 \cdot 29 \\
12 \cdot 38 \\
10 \cdot 42 \\
0.48 \\
0 \cdot 20 \\
0 \cdot 19 \\
1 \cdot 68 \\
8 \cdot 75\end{array}$ & $\begin{array}{r}-\overrightarrow{40 \cdot 21} \\
13 \cdot 23 \\
12 \cdot 10 \\
0 \cdot 68 \\
2 \cdot 52 \\
0 \cdot 89 \\
4 \cdot 75 \\
2 \cdot 50\end{array}$ & $\begin{array}{r}40.61 \\
38 \cdot 31 \\
13 \cdot 02 \\
11 \cdot 15 \\
0.66 \\
0.18 \\
0.26 \\
3.70 \\
6.48\end{array}$ & $\begin{array}{r}\overrightarrow{7} \\
40 \cdot 23 \\
13 \cdot 27 \\
11 \cdot 56 \\
0 \cdot 75 \\
4 \cdot 10 \\
0 \cdot 34 \\
4 \cdot 20 \\
2 \cdot 04\end{array}$ & $\begin{array}{l}0.12 \\
0.76 \\
0.60 \\
0.78 \\
0.30 \\
0.57 \\
0.35 \\
0.82 \\
0.79\end{array}$ & $\begin{array}{l}0.24 \\
1.50 \\
1 \cdot 19 \\
1.53 \\
0.59 \\
1 \cdot 12 \\
0.69 \\
1.61 \\
1.54\end{array}$ & $\begin{array}{l}0.33 \\
1.98 \\
1.57 \\
2 \cdot 01 \\
0.77 \\
1.47 \\
0.91 \\
2 \cdot 11 \\
2 \cdot 02\end{array}$ \\
\hline
\end{tabular}

* Least squares means for three-, four- and eight-cell embryos are those calculated following covariance adjustment for number of embryos recovered.

$\dagger$ Least significant difference between means required to reach statistical significance at the $5 \%$ and $1 \%$ level, respectively.

$¥$ Four to six blastomeres.

$\$$ Seven to ten blastomeres.

TABLE 2

MALE AND FEMALE REGTAL TEMPERATURE, NUMBER OF CORPORA LUTEA, IMPLANT SITES, VIABLE AND NON-VIABLE FETUSES AT DAY 10 OF GESTATION (MEAN NUMBER/ FEMALE \pm S.E.) IN MICE

\begin{tabular}{|c|c|c|c|c|c|c|c|}
\hline \multirow[b]{2}{*}{ Characteristic } & \multicolumn{5}{|c|}{ Treatment groups } & \multicolumn{2}{|c|}{ L.S.D.* } \\
\hline & Control & $\begin{array}{c}\text { Female } \\
\text { stress }\end{array}$ & $\begin{array}{l}\text { Male } \\
\text { stress }\end{array}$ & $\begin{array}{l}\text { Combined } \\
\text { stress }\end{array}$ & $\pm S . E$. & $5 \%$ & $1 \%$ \\
\hline $\begin{array}{l}\text { Male temp. }\left({ }^{\circ} \mathrm{C}\right) \\
\text { Fernale temp. }\left({ }^{\circ} \mathrm{C}\right) \\
\text { Corpora lutea } \\
\text { Implant sites } \dagger \\
\text { Viable fetuses } \\
\text { Non-viable fetuses } \dagger \\
\text { Non-viable fetuses } \ddagger\end{array}$ & $\begin{array}{r}38 \cdot 22 \\
38 \cdot 34 \\
13 \cdot 83 \\
13 \cdot 28 \\
12 \cdot 91 \\
0 \cdot 37 \\
0 \cdot 35\end{array}$ & $\begin{array}{r}-\overline{40 \cdot 09} \\
12 \cdot 83 \\
7 \cdot 24 \\
6 \cdot 82 \\
0 \cdot 42 \\
0 \cdot 48\end{array}$ & $\begin{array}{r}40 \cdot 61 \\
38 \cdot 31 \\
13.48 \\
5 \cdot 65 \\
4 \cdot 69 \\
0.96 \\
1 \cdot 49\end{array}$ & $\begin{array}{r}- \\
40 \cdot 15 \\
13 \cdot 81 \\
1.93 \\
1 \cdot 49 \\
0.44 \\
0.79\end{array}$ & $\begin{array}{l}0.12 \\
0.08 \\
0.43 \\
0.73 \\
0.76 \\
0.40 \\
0.34\end{array}$ & $\begin{array}{l}0.24 \\
0.10 \\
0.86 \\
1.44 \\
1.50 \\
0.71 \\
0.67\end{array}$ & $\begin{array}{l}0.33 \\
0.22 \\
1.13 \\
1.91 \\
1.98 \\
0.93 \\
0.88\end{array}$ \\
\hline
\end{tabular}

* Least significant difference between least squares means required to reach statistical significance at the $5 \%$ and $1 \%$ level, respectively.

$\dagger$ Means adjusted by covariance for mean number of corpora lutea (13.49).

$\ddagger$ Means calculated using only females with one or more implant sites.

the proportion of two-cell and four-cell embryos. There was also an increase $(P<0.05)$ in the number of three-cell embryos in the female stress, compared to the control, group (Table 1). By contrast, an increase $(P<0 \cdot 05)$ in the proportion of four-cell embryos was the only comparable effect apparent in the male stress group. 
The number of eight-cell embryos exemplifies the general effect of male and female treatment on retardation of preceding developmental stages. Thus, female treatment resulted in a significant reduction in the number of apparently normal eight-cell embryos $(P<0.01)$ with the female stress and combined stress groups having $22 \%$ and $18 \%$, respectively, of embryos recovered. This was in direct contrast to the control and male stress groups where eight-cell embryos constituted $77 \%$ and $55 \%$ of the embryos recovered, respectively. Although there was a significant $(P<0.01)$ reduction in the number of eight-cell embryos

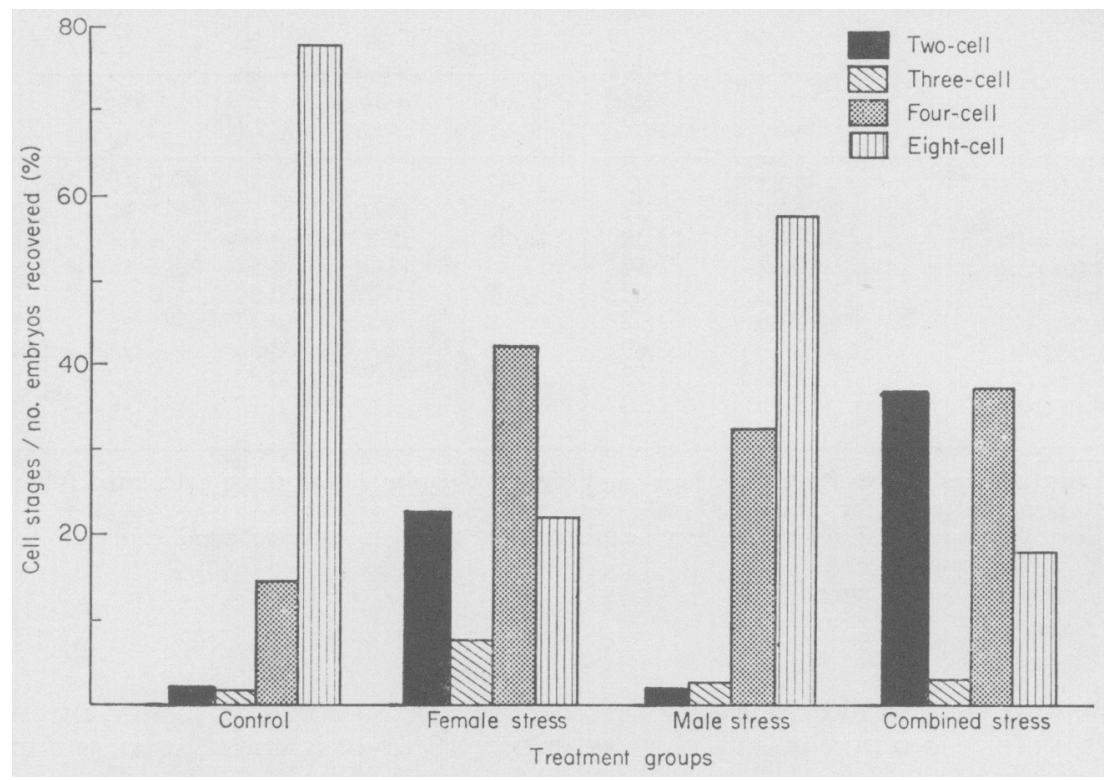

Text-Fig. 2. Distribution of two-, three-, four- and eight-cell embryos ( $\%$ total embryos) recovered from female mice of different treatment groups at $54 \mathrm{hr}$ gestation.

from the male stress group, a marked difference in the pattern of developmental retardation was apparent between the effects of male and female treatment. Furthermore, many embryos recovered from stressed females, in contrast to those from the control and male stress groups, were extremely variable in both the number and size of the blastomeres. This, together with the increased proportion of three-cell embryos, suggests asynchronous division of the blastomeres.

\section{Incorporation of $\left[{ }^{3} \mathrm{H}\right]$ uridine at $54 \mathrm{hr}$ gestation}

Owing to the developmental retardation apparent morphologically, the numbers of both four- and eight-cell embryos available for autoradiography differed between treatment groups. To avoid bias, those females which did not have embryos represented in either the four- or eight-cell stage were deleted from the respective analyses (Bellvé, 1970). Four-cell embryos were available from 114 females, and eight-cell embryos from 117 females. The data were then analysed by covariance techniques, adjusting for the number of embryos in each cell stage examined after autoradiography. 
The percentages of embryos that were classified 'completely labelled' are presented graphically in Text-fig. 3 and the means for all four labelling classifications are given separately in Table 3 . Female treatment caused a

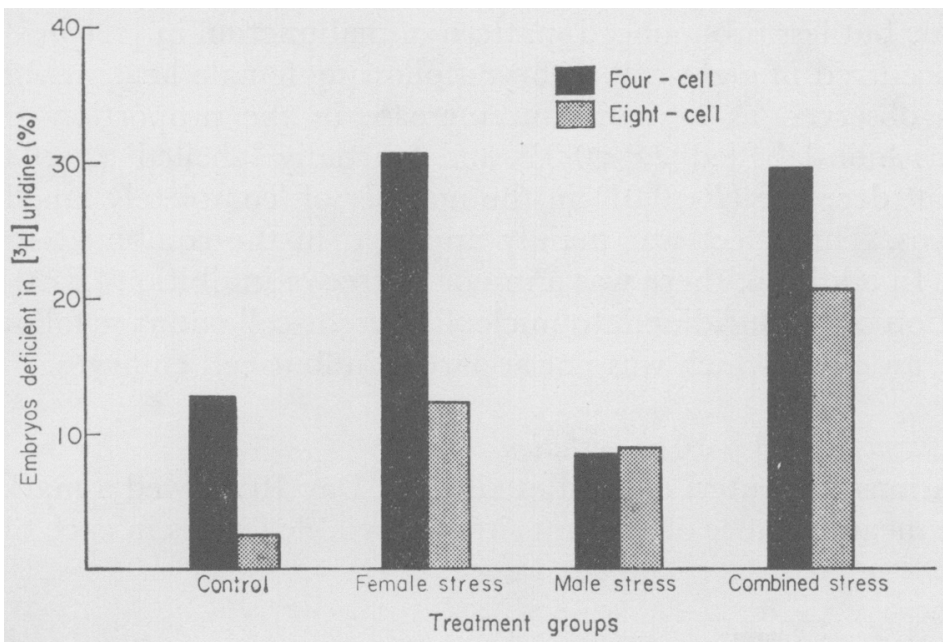

TEXT-FIG. 3. Effect of temperature stress upon the number of four- and eight-cell mouse embryos in which all blastomeres incorporated $\left[{ }^{3} \mathrm{H}\right]$ uridine (classified "completely labelled') after an incubation period of $60 \mathrm{~min}$ and $30 \mathrm{~min}$, respectively, at $54 \mathrm{hr}$ gestation. Data is expressed as $\%$ embryos subjected to autoradiography.

TABLE 3

INGORPORATION OF $\left[{ }^{3}\right.$ H] URIDINE BY FOUR- AND EIGHT-CELL EMBRYOS DURING INCUBATION in vitro FOLLOWING REGOVERY AT 54 HR GESTATION (MEAN NUMBER/ FEMALE \pm S.E. $) *$ IN MICE

\begin{tabular}{|c|c|c|c|c|c|c|c|}
\hline & \multicolumn{5}{|c|}{ Treatment groups } & \multicolumn{2}{|c|}{ L.S.D. $†$} \\
\hline & Control & $\begin{array}{c}\text { Female } \\
\text { stress }\end{array}$ & $\begin{array}{l}\text { Male } \\
\text { stress }\end{array}$ & $\begin{array}{c}\text { Combined } \\
\text { stress }\end{array}$ & \pm S.E. & $5 \%$ & $1 \%$ \\
\hline $\begin{array}{l}\text { Four-cell-embryos } \\
\text { Non-labelled } \\
\text { Partially labelled } \\
\text { Incompletely labelled } \\
\text { Completely labelled }\end{array}$ & $\begin{array}{l}0 \cdot 55 \\
0 \cdot 13 \\
0 \cdot 55 \\
4 \cdot 16\end{array}$ & $\begin{array}{l}1 \cdot 10 \\
0.56 \\
0 \cdot 69 \\
3 \cdot 04\end{array}$ & $\begin{array}{l}0 \cdot 33 \\
0 \cdot 14 \\
0 \cdot 62 \\
4 \cdot 30\end{array}$ & $\begin{array}{l}1 \cdot 10 \\
0 \cdot 52 \\
0 \cdot 71 \\
3 \cdot 10\end{array}$ & $\begin{array}{l}0.20 \\
0.14 \\
0.15 \\
0.24\end{array}$ & $\begin{array}{l}0.40 \\
0 \cdot 28 \\
0 \cdot 29 \\
0.48\end{array}$ & $\begin{array}{l}0 \cdot 52 \\
0 \cdot 37 \\
0 \cdot 39 \\
0 \cdot 63\end{array}$ \\
\hline $\begin{array}{l}\text { Eight-cell-embryos } \\
\text { Non-labelled } \\
\text { Partially labelled } \\
\text { Incompletely labelled } \\
\text { Completely labelled }\end{array}$ & $\begin{array}{l}0 \cdot 08 \\
0 \cdot 07 \\
0 \cdot 55 \\
5 \cdot 69\end{array}$ & $\begin{array}{l}0 \cdot 30 \\
0 \cdot 48 \\
0 \cdot 80 \\
4 \cdot 75\end{array}$ & $\begin{array}{l}0 \cdot 17 \\
0.40 \\
0 \cdot 82 \\
5 \cdot 01\end{array}$ & $\begin{array}{l}0 \cdot 65 \\
0 \cdot 68 \\
0 \cdot 80 \\
4 \cdot 27\end{array}$ & $\begin{array}{l}0.18 \\
0.17 \\
0.16 \\
0.23\end{array}$ & $\begin{array}{l}0 \cdot 36 \\
0 \cdot 33 \\
0 \cdot 32 \\
0 \cdot 46\end{array}$ & $\begin{array}{l}0.47 \\
0 \cdot 44 \\
0 \cdot 42 \\
0.60\end{array}$ \\
\hline
\end{tabular}

* Least squares means for number of four-cell and eight-cell embryos within each of the labelling classifications are adjusted for number of four-cell and number of eight-cell embryos subjected to autoradiography, respectively, where linear or linear and quadratic effects are significant.

$\dagger$ Least significant difference between means required to reach statistical significance at the $5 \%$ and $1 \%$ level, respectively.

significant $(P<0.01)$ increase in both the mean number of four-cell embryos classified as 'non-labelled' and 'partially labelled' when compared to control embryos. As a result, there was a decrease $(P<0.01)$ in the mean number of 
'completely labelled' embryos (Table 3). This reduction in the ability of these embryos to incorporate $\left[{ }^{3} \mathrm{H}\right]$ uridine into nucleoli is evident in both female stress and combined stress. In contrast, this effect was not observed among fourcell embryos recovered after male stress.

A similar, but less pronounced, pattern of malfunction in $\left[{ }^{3} \mathrm{H}\right]$ uridine incorporation occurred in eight-cell embryos following female heat treatment. This effect was observed as a significant increase in the proportion of embryos classified as 'non-labelled' $(P<0.05)$ and 'partially labelled' $(P<0.01)$ and a concomitant decrease $(P<0.01)$ in the number of 'completely labelled' eightcell embryos. This effect was mainly apparent in the combined stress group (Table 3$)$. In addition, there was a minor degree of inhibition $(P<0.05)$ in the incorporation of $\left[{ }^{3} \mathrm{H}\right]$ uridine into nucleoli of eight-cell embryos following male treatment, an effect which was not apparent in four-cell embryos.

\section{Embryonic survival at Day 10 of gestation}

Observations from uteri of females killed at Day 10 showed a marked reduction in the mean number of implant sites and viable fetuses in each of the stress

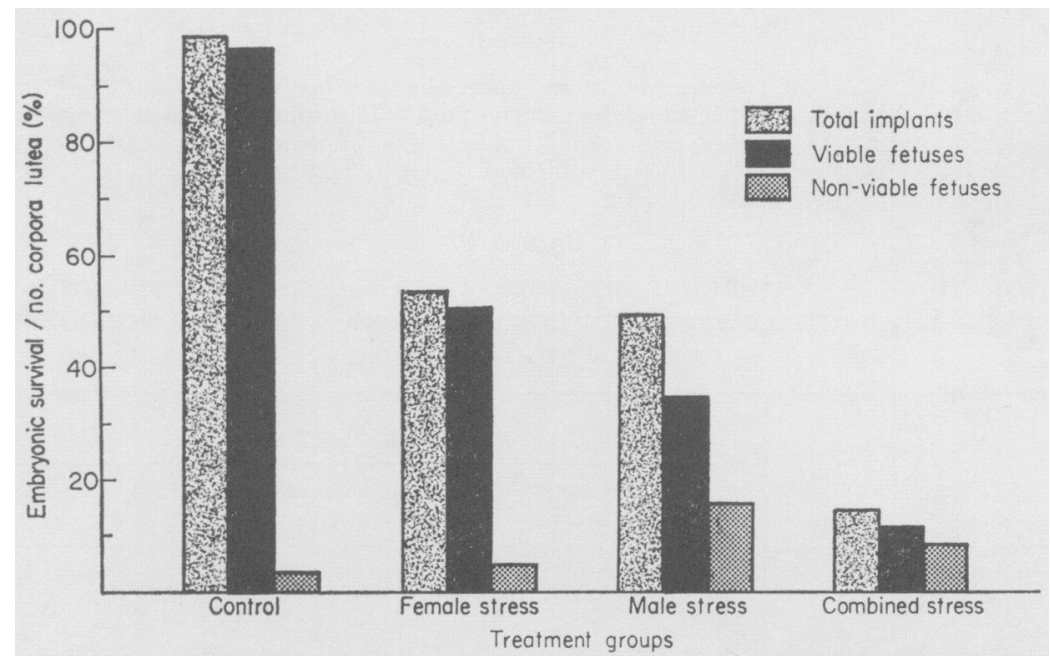

Text-Fig. 4. Mean number of implant sites, viable and non-viable fetuses $(\% \mathrm{cr})$ in mice from the treatment groups at Day 10 of gestation. Mean number of non-viable fetuses was determined using only those females with one or more implant sites (refer to Table 2).

treatments (Table 2, Text-fig. 4). Examination of the means, adjusted by covariance for number of GL, showed that significantly $(P<0.01)$ fewer embryos per litter survived to induce implant sites when the male was stressed before mating (5.65) than after stressing the female (7.24). A similar pattern occurred in the mean number of viable fetuses per litter. The analysis of covariance indicated a significant male $\times$ female treatment interaction in number of viable fetuses $(P<0.05)$.

Significant $(P<0.01)$ variation among individual males within male treatments was evident for number of implant sites and number of viable fetuses in 
the females. In both instances, the greater part of this variation was due to differences among the stressed males. Furthermore, the significant $(P<0.05)$ males within male $\times$ female treatment interactions in number of implant sites and viable fetuses point out that the ranking of individual males, based on their response to stress, was altered after superimposing female stress.

To examine the extent of mortality that occurred nearer the time of implantation, the data on number of non-viable fetuses were analysed, using only those females with one or more implant sites. This analysis indicated a significant effect due to stressing the male $(P<0.01)$ but an expected female effect was not observed. Further, this effect was more evident in the male stress than in the combined stress group (Table 2, Text-fig. 4).

\section{DISGUSSION}

Exposure of female mice to high temperature resulted in an increase in mean rectal temperature and a marked decrease in both the number of embryos that induced implant sites and the number of viable fetuses at Day 10 of gestation. The extent of this loss approximated to that observed in previous experiments at comparable temperature and period of exposure (Pennycuik, 1967; Elliott, Burfening \& Ulberg, 1968), but differed in that little embryonic and fetal loss was evident at or after implantation. Exposing males to the same environment induced a greater fetal loss as determined at Day 10 of gestation. The considerable variation in embryonic mortality among the offspring of stressed males may, in part, have been due to the different degree of susceptibility of individual males to high temperature. It could also have been due to differences in the extent of embryo mortality which exist between successive matings of each stressed male, a phenomenon observed previously (Burfening et al., 1970).

The male stress and female stress groups resulted in $53.7 \%$ and $41.9 \%$ implant sites, respectively, when expressed as a percentage of the adjusted mean number of CL (Table 2). Therefore, if the effects of male and female stress are independent, the probability of survival in the combined stress group would be $22.5 \%$, which contrasts with the $14.3 \%$ realized. A similar calculation with the number of viable implants gives a probability of $17.6 \%$ compared to the $11.1 \%$ obtained. In both cases, the probability value exceeds that observed, showing that the male and female treatment effects were not operating independently in the combined stress group. Thus, embryos fertilized by heat-stressed spermatozoa are more prone to further damage during subsequent exposure of the female. This implies that the two treatment effects may be operating through a similar mechanism.

Among control females, the number of viable fetuses at Day 10 of gestation was the same as the number of 54-hr morphologically (four-cell and eight-cell) or functionally (incorporation of $\left[{ }^{3} \mathrm{H}\right]$ uridine) normal embryos. In the female stress group, the number of functionally normal embryos, although substantially reduced, corresponds to the number surviving at Day 10 of pregnancy. Thus, the major proportion of embryonic loss following female stress was due to developmental arrest and/or retardation at the two-cell stage. Those embryos 
which reach the four- or eight-cell stage and demonstrate normal function may continue development.

In both male stress and combined stress, the number of viable fetuses is much less than would be expected from the 54-hr data. Therefore, neither gross morphology nor function at $54 \mathrm{hr}$ gestation gave any indication as to which, or how many, embryos were destined to die after stressing the male. It is evident, then, that the major portion of this mortality occurred at a later stage of development. This is further indicated by the greater number of non-viable fetuses observed at Day 10, these presumably being induced by embryos expressing a lethal abnormality nearer the time of implantation (Burfening $e t$ $a l ., 1970)$. The suppression of $\left.{ }^{3} \mathrm{H}\right]$ uridine incorporation in a small proportion of eight-cell, but not four-cell, embryos indicates that the malfunction due to male stress may become more apparent during the early morula stage.

By contrast, the malfunction in $\left[{ }^{3} \mathrm{H}\right]$ uridine incorporation in nucleoli of embryos of stressed females was more apparent in four- than in eight-cell embryos. It was equally clear that not all blastomeres of an affected embryo failed to incorporate $\left[{ }^{3} \mathrm{H}\right]$ uridine, indicating that some blastomeres within an embryo probably remained viable for longer periods after stress than others. Continued division of these apparently normal blastomeres would account for the irregular number of cells, or asynchronous division, observed in some embryos after female treatment.

\section{AGKNOWLEDGMENTS}

The author extends his sincere appreciation to Dr Eugene J. Eisen, Department of Animal Science, North Carolina State University, for his counsel and advice on statistical procedures. Recognition is also extended to Dr L. C. Ulberg, Mrs C. A. Rowland, Mrs A. Ticehurst, Mr C. Marsh, Jr, and Mr T. L. Wagoner of the Reproductive Physiology Research Laboratories at the North Carolina State University.

\section{REFERENCES}

Bellvé, A. R. (1970) A contrast of normal and abnormal development in the mouse. Ph.D. thesis, North Carolina State University at Raleigh. University Microfilm, Ann Arbor, Michigan.

Brinster, R. L. (1969) Mammalian embryo culture. In: The Mammalian Oviduct. Comparative Biology and Methodology, p. 419. Eds. E. S. E. Hafez and R. J. Blandau. University of Chicago Press.

BRown, D. D. (1964) RNA synthesis during amphibian development. F. exp. Zool. 157, 101.

Burfening, P. J., Elliott, D. S., Eisen, E. J. \& UlberG, L. C. (1970) Survival of embryos resulting from spermatozoa produced by mice exposed to elevated ambient temperature. F. Anim. Sci. 30, 578 .

ELLIOTT, D. S. (1968) Developmental alterations in mouse embryos subjected to temperature stress in vivo during the first cell division. Ph.D. thesis, North Carolina State University at Raleigh. University Microfilm, Ann Arbor, Michigan.

Elliott, D. S., Burfening, P. J. \& Ulberg, L. C. (1968) Subsequent development during incubation of fertilized mouse ova stressed by high ambient temperatures. F. exp. Zool. 169, 481.

Hallberg, R. L. \& Brown, D. D. (1969) Co-ordinated synthesis of some ribosomal proteins and ribosomal RNA in embryos of Xenopus laevis. 7. molec. Biol. 46, 393.

HaRveY, W. R. (1960) Least squares analysis of data with unequal subclass numbers. Tech. Bull. U.S. Dep. Agric. ARS-20-8:1.

Kodak Scientific and Technical Data (1966) Kodak materials for nuclear physics and autoradiography. Pamphlet No. P-64. Eastman Kodak Company, Rochester, New York. 
Pennycuik, P. R. (1967) A comparison of the effects of a range of high environmental temperatures and of two different periods of acclimatization in the reproductive performances of male and female mice. Aust. F. exp. Biol. med. Sci. 45, 527.

Skalko, R. G. \& Morse, J. M. D. (1969) The differential response of the early mouse embryo to actinomycin $\mathrm{D}$ in vitro. Teratology, $2,47$.

Snedecor, G. W. \& Cochran, W. B. (1967) Statistical methods. Iowa State University Press, Ames, Iowa. 